\title{
IMPLEMENTATION OF CLUSTER K-MEANS FOR THE EAST JAVA ENVIRONMENTAL HEALTH AREAS GROUPING IN 2017
}

\author{
Saarah Puspita Dewi ${ }^{1}$, Mahmod Bin Othman ${ }^{2}$ \\ ${ }^{1}$ Department of Biostatistics and Population, Faculty of Public Health, Universitas Airlangga, 60115 Surabaya, East Java, \\ Indonesia \\ ${ }^{2}$ Department of Fundamental and Applied Sciences, Universiti Teknologi Petronas, 32610 Seri Iskandar, Perak Darul \\ Ridzuan, Malaysia \\ Corresponding Author: Saarah Puspita Dewi \\ E-mail: Saarah.puspita.dewi-2015@fkm.unair.ac.id
}

\begin{abstract}
An unhealthy environment is a threat that possibly leads to diseases. Consequently, effective environmental monitoring is needed as an effort to improve environmental quality. The basis for implementing the program to determine the fulfilment of environmental health indicators is program targets. Achievements will be compared with program targets as program evaluations to determine the distribution priority areas for improving environmental health indicators. In order to illustrate the coverage of environmental health services by each district or city in East Java Province, K-Means cluster analysis was administered. The objective of cluster analysis application is to determine the regional distribution status based on the environmental health indicators' achievement in East Java in 2017. This type of research is a descriptive study using non-reactive methods. The data collected was secondary data based on indicators on the Environmental Health Program in 2017. The results of this study illustrated the distribution of environmental health areas in East Java, there are 3 clusters including cluster 1 (high strata) covering 17 districts or cities, where several environmental health indicators had fulfilled the target, cluster 2 (middle strata) covers 16 districts or cities where several environmental health indicators were almost reaching the target. Finally, cluster 3 (lower strata) covers 5 districts, where several environmental health indicators had not been achieved yet. In conclusion, the Environmental Health Program in 2017 at East Java Province was considered quite successful.
\end{abstract}

Keywords: cluster analysis, environmental health program, East Java Province

\begin{abstract}
ABSTRAK
Lingkungan yang tidak sehat menjadi ancaman yang dapat menimbulkan sebuah penyakit. Sebab itu perlu adanya pengawasan lingkungan yang efektif sebagai upaya untuk meningkatkan kualitas lingkungan. Dasar pelaksana program untuk menentukan keberhasilan indikator kesehatan lingkungan yaitu adanya target program. Capaian akan dibandingkan dengan target program berperan sebagai evaluasi program untuk menentukan sebaran wilayah yang menjadi prioritas perbaikan indikator kesehatan lingkungan. Untuk menggambarkan cakupan pelayanan kesehatan lingkungan berdasarkan kabupaten/kota di Provinsi Jawa Timur dapat dilakukan dengan analisis klaster K-Means. Tujuan yaitu penerapan analisis klaster untuk mengetahui status sebaran wilayah berdasarkan capaian indikator kesehatan lingkungan di Provinsi Jawa Timur tahun 2017. Jenis penelitian ini merupakan penelitian yang bersifat deskriptif menggunakan metode non reaktif. Data yang dikumpulkan merupakan data sekunder yaitu data indikator pada Program Penyehatan Lingkungan tahun 2017 yang diperoleh dari Profil Kesehatan Provinsi Jawa Timur tahun 2017. Hasil Penelitian ini menggambarkan sebaran wilayah kesehatan lingkungan di Provinsi Jawa Timur terdapat 3 klaster yaitu klaster 1 (strata tinggi) meliputi 17 Kabupaten/Kota, dimana capaian beberapa indikator kesehatan lingkungan sudah memenuhi target. klaster 2 (strata sedang) meliputi 16 Kabupaten/Kota dimana capaian beberapa indikator kesehatan lingkungan hampir mencapai target. Terakhir klaster 3 (strata rendah) meliputi 5 Kabupaten, dimana capaian beberapa indikator kesehatan lingkungan yang belum mencapai target. Kesimpulan adalah program penyehatan lingkungan di Provinsi Jawa Timur dianggap cukup berhasil.
\end{abstract}

Kata kunci: analisis klaster, program penyehatan lingkungan, Provinsi Jawa Timur 


\section{INTRODUCTION}

Health is the main aspect that affects the human resources' quality in supporting sustainable development. Someone's health status is resulted from the accumulation of 3 factors including the host, agent, and environment. Environmental factor act as a counterweight between the host and agent in the epidemiological triangle. These three factors, when run synergistically, will increase the degree of public health (Ragil and Dyah, 2017).

Progressively, the number of population in Indonesia is growing and contributing to the fulfilment necessity of human needs that are not only basic needs such as clothing, shelter, and food, but also the needs for rudimentary hygiene facilities in order to be able to live properly (Hartanti, Lubis and Butar-Butar, 2013).

As the medical health realm improved, several efforts have been attempted to make environmental health as a movement that supports the healthy development paradigm that serves as a guideline called "Health Paradigm" (Febrian, 2012). Activities undertaken are preventive and promotive, including efforts to prevent healthy people from getting ill due to negative environmental impacts without eliminating medicinal efforts.

Environmental health monitoring is a series of activities or processes carried out to improve the quality of the environment so that it does not interfere human's health (Indonesian Ministry of Health Decree Number 1428/ MENKES/SK/XII/2006 Concerning Pedoman Penyelenggaraan Keseharan Lingkungan Puskesmas).

The environmental health program has several indicator that are considered covering healthy houses, community access to proper water sources, decent quality of drinking water for the providers, community access to the hygienic lavatories, villages that implement Community-Based Total Sanitation (CBTS), Public Facilities that fulfilled hygiene requirements of health standards and Food Management Sites (FMS). In 2017, the percentage of each indicator of the environmental health program in East Java Province, respectively was $69.34 \% ; 76.44 \%$; $82.29 \% ; 78.6 \% ; 75.1 \%$; $76.41 \%$; and $32.31 \%$ (East Java Provincial Health Office, 2018).

Grouping is necessary, since the spread is not well-balanced, to classify the indicator for environmental health program into "high", "medium", and "low". Results' grouping of indicator coverage in environmental health program illustrate regional groups with the same variable characteristics.

Cluster analysis is a multivariate technique utilized to process the grouping of several variables. Cluster analysis is a statistical tool that can categorize objects into several groups or clusters that differ in characteristics from one group to another, in other word, one group or cluster has objects that are similar in characteristics. Objects that have been categorized in one group or cluster have a proximity distance. Euclidean distance is one type of distance measurements between object pairs in cluster analysis (Fathia, Rahmawati and Tarno, 2016).

One of the most distinctive features of the cluster or group formed is the high degree of similarity of members or objects in one cluster but has a high difference in the members or objects of other clusters (Alfina, Santosa and Barakbah, 2012).

$\mathrm{K}-\mathrm{Means}$ cluster analysis is included in the non-hierarchical cluster method which groups data into several clusters or groups (Bastian, Sujadi and Febrianto, 2018). Before conducting cluster analysis using the K-Means method, it is better to determine the number of $\mathrm{k}$, i.e. the number of groups or clusters first. K-Means is a simple cluster method and suitable since it is efficient for processing large numbers of objects, scaling ratio or continuous data, and forming clusters quickly (Mukti and Wibowo, 2017).

The purpose of this research is to determine the distribution status of the coverage indicators in the environmental health program based on the cluster analysis of the KMeans method.

\section{METHODS}

This research is a non-reactive research for it is conducted on subjects who are unaware that they are being observed or research type for secondary data (Kuntoro, 2011).

This research was conducted in East Java Provincial Health Office by taking secondary data based on Environmental Health Program of East Java Province in 2017. The study was carried out from January 2019 to February 2019. The observation units used in this study were total 38 districts or cities in East Java. 
Data collection was administered through the stages of recording indicators and targets for Environmental Health Program in 38 districts/cities member of East Java Province based on East Java Province Health Profile in 2017.

The required data including coverage percentage of healthy houses (X1), coverage percentage of community access to proper water sources (X2), coverage percentage of decent quality of drinking water providers (X3), coverage percentage of community access to the hygienic lavatories (X4), coverage percentage of villages that implement CBTS (X5), coverage percentage of Public Facilities that fulfilled hygiene requirements (X6) and coverage percentage of Food Management Sites that fulfilled hygiene standards (X7).

The data analysis technique used the KMeans cluster analysis method to describe the Environmental Health area of East Java Province in 2017 carried out through the following stages (Bangun, 2016):

The first stage was the selection of variables in the Environmental Health Program that would be used for clustering. The second stage was seeing the scale of the data and the size of the unit in the variable under study. The standardization process was carried out when the research variables differ in the size of the data unit. The third stage was factor analysis which included fulfilling the assumptions of data sufficiency and variables that were correlated using the Keizer Meyer Olkin (KMO) test and the Barlett's of Sphericity test.
The fourth stage was $\mathrm{K}$ cluster analysis using Euclidian distance and determining from the start the number of clusters desired. Finally, presented the results of descriptive analysis and cluster analysis based on the coverage of the Environmental Health Program indicators.

\section{RESULT}

\section{Descriptive Analysis}

Table 1 shows that there were 38 observation units in East Java Province on each indicator covered in 29 districts and 9 cities. The largest standard deviation value belonged to the coverage of villages that implement CBTS and the smallest value belonged to the coverage of public facilities that fulfilled hygiene requirements. This indicates that the highest diversity of data in each district or city occurred in the indicators for the coverage of villages that implement CBTS and the lowest occurred in the coverage of public facilities that fulfilled hygiene requirements. The data diversity on each environmental health indicator does not have a relatively same wide range.

\section{Factor Analysis}

Before proceeding to the cluster analysis stage, two assumptions must be fulfilled, i.e. representative samples using the Kaiser Mayer Olkin Test (KMO test) and the relationship or correlation between variables using the Bartlett's of Sphericity Test.

Table 1. Coverage of Environmental Health Indicators in East Java Province 2017 Analysis

\begin{tabular}{|c|c|c|c|c|}
\hline \multirow{2}{*}{ Environmental Health Indicator } & \multicolumn{4}{|c|}{ Coverage Percentage } \\
\hline & Min & $\operatorname{Max}$ & Average Scope & Standard deviation \\
\hline Coverage of healthy houses (X1) & 25.08 & 96.84 & 70.53 & 16.40 \\
\hline $\begin{array}{l}\text { Coverage of community access to proper } \\
\text { water sources (X2) }\end{array}$ & 17.00 & 100.00 & 78.70 & 19.18 \\
\hline $\begin{array}{l}\text { Coverage of decent quality of drinking } \\
\text { water providers according to health } \\
\text { requirements (X3) }\end{array}$ & 0.00 & 100.00 & 77.06 & 20.55 \\
\hline $\begin{array}{l}\text { Coverage of community access to the } \\
\text { hygienic lavatories (X4) }\end{array}$ & 25.15 & 100.16 & 80.07 & 17.26 \\
\hline $\begin{array}{l}\text { Coverage of villages implementing CBTS } \\
\text { (X5) }\end{array}$ & 14.30 & 100.00 & 80.05 & 21.74 \\
\hline $\begin{array}{l}\text { Coverage of Public Facilities that fulfilled } \\
\text { hygiene requirements (X6) }\end{array}$ & 22.30 & 93.90 & 78.03 & 13.85 \\
\hline $\begin{array}{l}\text { Coverage of Food Management Sites that } \\
\text { fulfilled hygiene standards (X7) }\end{array}$ & 22.40 & 95.06 & 63.25 & 16.18 \\
\hline
\end{tabular}


Table 2. KMO and Barlett of Sphericity Test

\begin{tabular}{cccc}
\hline Kaiser Mayer Olkin Measure & \multicolumn{3}{c}{ Bartlett's Test of Sphericity } \\
\cline { 2 - 4 } of Sampling Adequacy & Approx. Chi-Square & Df & Sig. \\
\hline 0.640 & 69.692 & 21 & 0.000 \\
\hline
\end{tabular}

Table 3. Final Cluster Centre

\begin{tabular}{|c|c|c|c|c|}
\hline \multirow{2}{*}{ Environmental Health Indicator } & \multirow{2}{*}{$\begin{array}{l}\text { Provincial } \\
\text { Target }\end{array}$} & \multicolumn{3}{|c|}{ Cluster } \\
\hline & & 1 & 2 & 3 \\
\hline Coverage of healthy houses (X1) & $75 \%$ & $80.53(* * *)$ & $63.66^{(* *)}$ & $58.49^{(*)}$ \\
\hline $\begin{array}{l}\text { Coverage of community access to proper } \\
\text { water sources (X2) }\end{array}$ & $85 \%$ & $89.12^{(* * *)}$ & $77.83^{(* *)}$ & $46.04^{(*)}$ \\
\hline $\begin{array}{l}\text { Coverage of decent quality of drinking } \\
\text { water providers according to health } \\
\text { requirements (X3) }\end{array}$ & $83 \%$ & $68.44^{(*)}$ & $87.09^{(* * *)}$ & $74.24^{(* *)}$ \\
\hline $\begin{array}{l}\text { Coverage of community access to the } \\
\text { hygienic lavatories (X4) }\end{array}$ & $77 \%$ & $92.00^{(* * *)}$ & $77.06^{(* *)}$ & $49.14^{(*)}$ \\
\hline $\begin{array}{l}\text { Coverage of villages implementing CBTS } \\
\text { (X5) }\end{array}$ & $66.76 \%$ & $88.11^{(* * *)}$ & $70.46^{(* * *)}$ & $83.36^{(* * *)}$ \\
\hline $\begin{array}{l}\text { Coverage of Public Facilities that fulfilled } \\
\text { hygiene requirements (X6) }\end{array}$ & $58 \%$ & $81.55^{(* * *)}$ & $73.87^{(* * *)}$ & $79.40^{(* * *)}$ \\
\hline $\begin{array}{l}\text { Coverage of Food Management Sites that } \\
\text { fulfilled hygiene standards (X7) }\end{array}$ & $32 \%$ & $72.77^{(* * *)}$ & $60.15^{(* * *)}$ & $40.82^{(* * *)}$ \\
\hline
\end{tabular}

Information: $(*)$ shows a low average, it has not reached the provincial target yet. $(* *)$ indicates a moderate mean, it is approaching the provincial target. $(* * *)$ shows a high average, it is above the provincial target.

When the KMO test value is between 0.5 to $1(0.5<\mathrm{KMO} \geq 1)$, it can be implied that the sample represent the population. Table 2 shows the KMO value of 0.640 means that the representative sample assumptions are fulfilled. While the hypothesis on the Bartlett's of Sphericity Test is:

$\mathrm{H} 0$ : There is no relationship between variables. $\mathrm{H} 1$ : There is a relationship between variables. Reject H0 if $p$ value $<\alpha=0.05$.

Based on Bartlett's test, it was shown that the known value of sig. $=0.0001$ (sig. $<\mathrm{A}=$ 0.05 ), meaning that there is a relationship between variables. Both assumptions are fulfilled, which indicates that the environmental health indicator data of East Java Province in 2017 is suitable for cluster analysis.

\section{K-Means Cluster Analysis}

The principle of grouping in the K-means method is to classify objects (districts or cities in East Java) based on the mean of the closest group. The district or city average results will be compared with the 2017 Environmental Health Program Targets. The complete cluster analysis results are shown in Table 3 .

Based on the results of K-Means cluster processing shown in Table 3, information about the mean values in the districts or cities which are included in each cluster is obtained. Cluster 1 has the same characteristics in the form of low coverage on variable $\mathrm{X} 3$, while variables $\mathrm{X} 1$, $\mathrm{X} 2, \mathrm{X} 4, \mathrm{X} 5, \mathrm{X} 6, \mathrm{X} 7$ are included as high coverage because they successfully reach the target set. Cluster 2 has the same characteristics in the form of medium coverage on variables $\mathrm{X} 1, \mathrm{X} 2, \mathrm{X} 4$, and high coverage on variables $\mathrm{X} 3$, $X 5, X 6$, and $X 7$. Cluster 3 has the same characteristics in the form of low coverage on 3 variables, i.e. $\mathrm{X} 1, \mathrm{X} 2$ and $\mathrm{X} 4$, medium coverage on variable $\mathrm{X} 3$, and high coverage on the remaining variables i.e. X5, X6, X7.

Table 4. Number of Members in a Cluster

\begin{tabular}{ccccc}
\hline \multicolumn{3}{c}{ Cluster } & \multirow{2}{*}{ Valid } & Missing \\
\hline 1 & 2 & 3 & & \\
\hline 17.000 & 16.000 & 5.000 & 38.000 & 0.000 \\
\hline
\end{tabular}



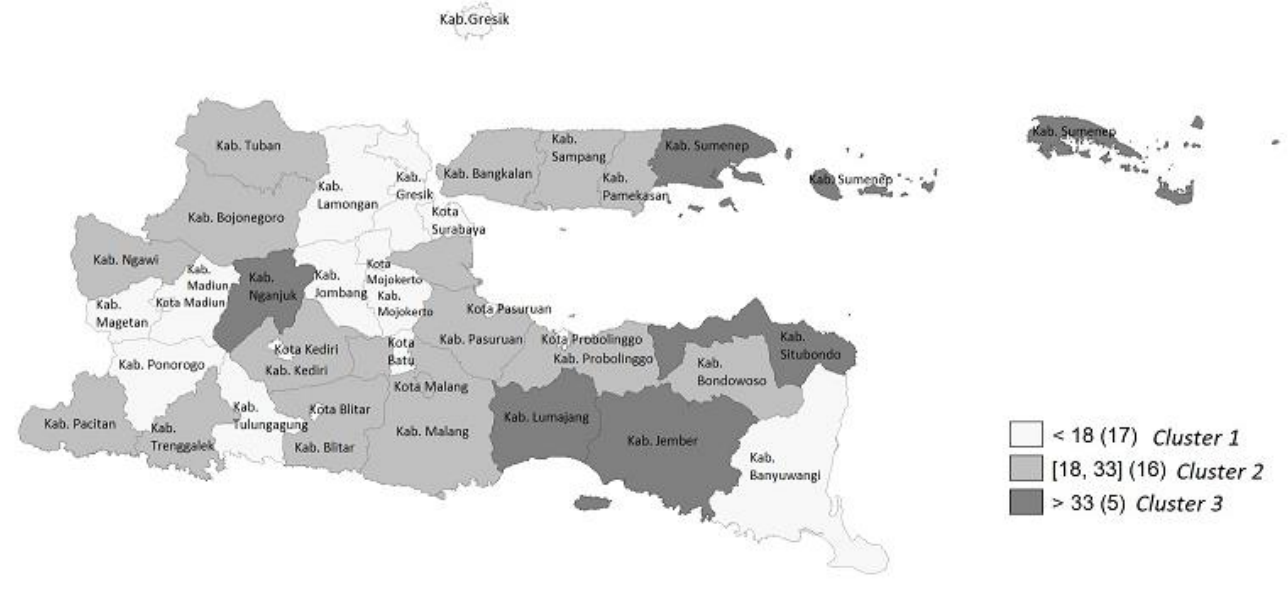

Figure 1. Map of Grouping 38 Districts or Cities based on the Environmental Health Program Indicators

Table 5. Test Variable Differences in Formed Clusters

\begin{tabular}{lcc}
\hline \multicolumn{1}{c}{ Variable } & F & Sig. \\
\hline Coverage of healthy homes (X1) & 8.222 & 0.001 \\
Coverage of community access to proper water sources (X2) & 19.605 & 0.000 \\
Coverage of decent quality of drinking water providers according to health & 4.004 & 0.027 \\
requirements (X3) & 34.949 & 0.000 \\
Coverage of community access to the hygienic lavatories (X4) & 3.096 & 0.058 \\
Coverage of villages implementing CBTS (X5) & 1.317 & 0.281 \\
Coverage of Public Facilities that fulfilled hygiene requirements (X6) & 13.449 & 0.000 \\
\hline Coverage of Food Management Sites that fulfilled hygiene standards (X7)
\end{tabular}

Based on Table 4, information regarding the number of members from the grouping of 38 regencies or cities in East Java Province into 3 clusters was obtained. Where cluster 1 members consist of 17 units, cluster 2 members consist of 16 units and cluster 3 members consist of 5 units.

Figure 1 shows a map of the distribution of grouping of 38 districts or cities covered in each cluster as follows: cluster 1 covering 9 districts and 8 cities in East Java, cluster 2 covering 15 districts, and 1 city in East Java, while cluster 3 covers 5 districts in Java East. A full description of the results can be seen in Figure 1.

Figure 1 shows the results of the analysis using a black and white grading map by dividing it into 3 clusters based on the Environmental Health Program indicators. White means the district or city covered in cluster 1 , gray means the district or city covered in cluster 2 and black means the district or city covered in cluster 3 ..

Table 5 shows the results of data processing of the 7 variables studied. There were 5 significant variables (sig. $<0.05$ ) as follows: coverage of healthy houses, coverage of community access to proper water sources, coverage of decent quality of drinking water providers according to health requirements, coverage of community access to the hygiene lavatories, coverage of villages implementing CBTS, coverage of Public Facilities that fulfilled hygiene requirements, and coverage of Food Management Sites that fulfilled hygiene standards. From these results, it can be concluded that there are significant differences between the three clusters which are shown by a significance variable.

Furthermore, according to the results, the largest $F$ value is 34,949 which can be interpreted that districts or cities in the coverage 
of community access to the hygiene lavatories in each cluster are very different. In conclusion, the higher the $\mathrm{F}$ value, the higher the difference between cluster 1 , cluster 2 , and cluster 3 for the concerned variable.

\section{DISCUSSION}

\section{Environmental Health Program's Achievement}

\section{Coverage of Healthy Houses (X1)}

A healthy house is one of the parameters assessed for efforts to improve the environment quality in order to prevent the development of germs and reduce the risk of transmitting a disease (Hakim, 2018). House is the part of primary human needs that support survival. Therefore, to make the house safe and comfortable, it must fulfil several criteria. Healthy house is a building inhabited by human being that must comply with health requirements including sanitation facilities, the physical condition of the house, and the behavior of residents inside it (Norihwadziyah and Keman, 2013).

The average coverage of healthy houses in East Java in 2017 was $70.53 \%$ which did not meet $75 \%$ of provincial target. Figures for 2017 have increased compared to 2016 which only $63.34 \%$ meaning that there is quality improvement by $7.19 \%$ (East Java Provincial Health Office, 2017). The largest coverage of healthy house in East Java was Batu by $96.84 \%$. While the smallest coverage belonged to Sampang by $25.08 \%$.

\section{Coverage of Community Access to Proper Water Sources (X2)}

In the health profile, the quality of drinking water sources assessed includes 3 types of wells: drilled with pumps, dugged with pumps, and dugged under protection. Then there are the water terminals, protected springs, rainwater harvesting system, and plumbing (Local Water Company). The water facilities have certain criteria or health requirements including distance of at least $10 \mathrm{~m}$ from a septic tank, waste container availability, and temporary or final landfill (East Java Provincial Health Office, 2018). The community is expected to participate in water quality monitoring activities especially in reporting when degradation in water quality occurs.
The average population access to decent or quality drinking water in East Java in 2017 is $78.70 \%$ which had not reached $85 \%$ of the provincial target. Figures for 2017 experienced an increase compared to 2016 which was only $75.52 \%$ so there was quality improvement of 3.18\% (East Java Provincial Health Office, 2017). The highest coverage of population access to decent or quality drinking water in East Java in 2017 was Pasuruan (city) and Madiun (city) by $100 \%$, while the lowest coverage was Nganjuk (district) by $17 \%$.

\section{Coverage of Drinking Water Quality in Drinking Water Providers (X3)}

Drinking water providers are all institutions under the auspices of the state or region or private sector or individuals or groups that carry out the organizing bussiness of drinking water supply (Indonesian Government Regulation Number 16 of 2005 concerning Pengembangan Sistem Penyediaan Air Minum).

Each district or city has a drinking water provider so that monitoring is needed by related parties as a form of supervision and maintaining the quality of the water produced. Hygiene inspection is administered by taking water samples to be examined through physical, bacteriological, and chemical examinations.

The average coverage of drinking water provider samples that fulfilled health requirements in East Java in 2017 is $77.06 \%$, which had not reached $83 \%$ of the provincial target. Figures for 2017 experienced a slight increase compared to 2016, which was $77.04 \%$ so there was quality improvement of $0.02 \%$ (East Java Provincial Health Office, 2017). The highest coverage of drinking water providers according to health requirements is Sidoarjo (city), Sampang (city), and Malang (city) by $100 \%$. While the lowest coverage was Mojokerto (district) by $0 \%$.

\section{Coverage of Community Access to the Hygienic Lavatories (X4)}

Proper sanitation facilities and infrastructure such as healthy lavatories must fulfill health standards including goose neckshaped toilets and have a septic tank, whether used by individuals or groups (East Java Provincial Health Office, 2018).

The average coverage of community access to the hygenic lavatories in East Java in 2017 
was $80.07 \%$, which has reached $77 \%$ of the provincial target. Figures for 2017 experienced an increase compared to 2016 which was $67 \%$ so there was quality improvement by $13.07 \%$ (East Java Provincial Health Office, 2017). The highest coverage of population access to proper sanitation (healthy latrines) was Blitar (city) by $100.16 \%$ while the lowest coverage was in Nganjuk (district) by $25.15 \%$.

\section{Coverage of Villages Implementing CBTS (X5)}

CBTS is an approach implemented to turn poor hygiene and sanitation behavior into the better one through community empowerment with triggering methods. Villages implementing CBTS are villages that have conducted at least 1 village's triggering activity, have a community work team, and have a follow-up agenda to achieve Total Sanitation. In the meantime, the CBTS village is a village which population is implementing totally the 5 CBTS pillars (East Java Provincial Health Office, 2018).

The average coverage of villages implementing CBTS in East Java in 2017 is 6384 villages or $80.05 \%$, which had reached 5676 villages or $66.76 \%$ of the provincial target. The highest coverage of villages implementing CBTS were 11 districts or cities with a percentage of $100 \%$, i.e. Magetan (district), Trenggalek (district), Pacitan (district), Lamongan (district), Situbondo (district), Probolinggo (city), Blitar (city), Batu (city), Madiun (city), Pasuruan (city), and Surabaya (city). While the one with the lowest coverage of villages implementing CBTS was Ngawi (district) by $14.3 \%$.

\section{Coverage of Public Facilities that Fulfilled Hygiene Requirements (X6)}

According to health profile, public facilities in East Java Province are locations or facilities provided by the government or private or individual that is used for the benefit of citizens in carrying out activities including health services (hospitals, PHC), educational facilities (elementary, Middle school, high school), and hotel (East Java Provincial Health Office, 2018). The aim of establishing the public facilities that fulfill health requirements is to protect officers, users, and the public itself to avoid adverse health risks.

The average coverage of public places according to health requirements in East Java in
2017 is $78.03 \%$ which had reached $58 \%$ of the provincial target. This figure had decreased compared to 2016, which was $80.95 \%$, therefore there was a decrease in quality by 2.92\% (East Java Provincial Health Office, 2017). The highest coverage of public facilities according to health requirements was Madiun (city) by $93.87 \%$ while the lowest coverage was Sampang (district) by $22.25 \%$.

\section{The Coverage of Food Management Sites that Fulfilled Hygiene Standards (X7)}

Food management site (FMS) is a business entity of food or beverage manufacturing service which includes: restaurants, catering, canteens, and street food stall (East Java Provincial Health Office, 2018). Restructuring FMS aims to improve the ability of the community in providing healthy, safe, hygienic, and quality food.

The average coverage of food management sites that fulfilled hygiene standards in East Java in 2017 is $63.25 \%$, which had reached $32 \%$ of the provincial target. The figure in $2017 \mathrm{had}$ increased in number compared to 2016 which was only $59.23 \%$, so there was quality improvement by $4.02 \%$ (East Java Provincial Health Office, 2017). The highest coverage of food management that fulfilled hygiene standards was Surabaya (city) by $95.06 \%$ while the lowest coverage was Nganjuk (district) by $22.40 \%$.

\section{Cluster Analysis}

Based on the results of data analysis on Environmental Health Indicators, it was found out that cluster 1 , which consists of 17 districts or cities in East Java, was in good environmental health status since it had reached the settled provincial target. Members who were included as the part of good environmental health status as follows: Mojokerto (district), Tulungagung (district), Madiun (district), Banyuwangi (district), Magetan (district), Ponorogo (district), Jombang (district), Lamongan (district), Jombang (district), Gresik (district), Madiun (city), Blitar (city), Pasuruan (city), Kediri (city), Probolinggo (city), Mojokerto (city), Batu (city), and Surabaya (city).

Most of the regions incorporated in cluster 1 are dominated by urban areas such as Surabaya, Batu, Madiun, Blitar, Gresik, and 
Lamongan have good economic growth during 2011-2015 (Nuraini, 2017).

Cluster 2 consists of 16 districts or cities that are included in the current environmental health status, which are Blitar (district), Trenggalek (district), Kediri (district), Pacitan (district), Probolinggo (district), Bondowoso (district), Malang (district), Sidoarjo (district), Pasuruan (district), Ngawi (district), Bojonegoro (district), Tuban (district), Pamekasan (district), Sampang (district), Bangkalan (district), and Malang (city) since the achievement of environmental health indicators almost fulfill the settled provincial target.

Finally, cluster 3 consists of 5 districts which have low environmental health status including Lumajang, Jember, Situbondo, Nganjuk, and Sumenep. These 5 districts have several environmental health indicators that have not reached the provincial target.

The development of the economic sector alongside the attempt of social needs' fulfilment must be counterpoising with attention to the environment. If the condition is unbalanced, it will lead to increasingly serious health problems with higher morbidity rates as a result of the environmental pollution. The quality of the environment is reciprocally related to community problems such as economic, social, and public health. One of the economic problems that affect the environment are population density.

Population density level in developed areas such as urban areas tends to be higher compared to the other regional parts such as rural areas. This condition is common since most people consider developed regions provide better livelihoods due to rapid economic development and the provision of more complete facilities and infrastructure especially in easier community access to facilities that support environmental health (Pratiwi, Santosa and Ashar, 2018).

\section{CONCLUSIONS AND SUGGESTIONS}

\section{Conclusion}

There are 3 optimal clusters in the indicator distribution areas of the Environmental Health Program in East Java Province in 2017. Cluster 1 consists of 17 districts or cities as the members where each member in cluster 1 has good strata environmental health area distribution. Cluster 2 has 16 districts or cities as the members in total where each member has moderate strata health environment distribution. Finally, cluster 3 with 5 districts or cities as the members, have low strata environmental health area distribution.

\section{Suggestion}

For researchers who are interested in further study, cluster analysis can be done with other methods to classify health data based on certain characteristics and utilize the Environmental Health Program data for deeper analysis (statistical analysis) so that more accurate information can be generated and can be taken into consideration in the program.

\section{REFERENCES}

Alfina, T., Santosa, B. and Barakbah, A.R., 2012. Analisa Perbandingan Metode Hierarchical Clustering, K-means dan Gabungan Keduanya dalam Cluster Data (Studi Kasus: Problem Kerja Praktek Jurusan Teknik Industri ITS). Jurnal Teknik ITS, 1(1), pp.521-525.

Bangun, R.H.B., 2016. Analisis Klaster Non Heirarki Dalam Pengelompokan Kabupaten/Kota di Sumatera Utara Berdasarkan Faktor Produksi Padi. Agrica (Jurnal Agribisnis Sumatera Utara), 4(1), pp.54-61.

Bastian, A., Sujadi, H. and Febrianto, G., 2018. Penerapan Algoritma K-Means Clustering Analysis pada Penyakit Menular Manusia (Studi Kasus Kabupaten Majalengka). Jurnal Sistem Informasi (Journal of Information System), 14(1), pp.26-32.

East Java Provincial Health Office, 2017. Profil Kesehatan Provinsi Jawa Timur Tahun 2016. Surabaya.

East Java Provincial Health Office, 2018. Profil Kesehatan Provinsi Jawa Timur Tahun 2017. Surabaya.

Fathia, A.N., Rahmawati, R. and Tarno, 2016. Analisis Klaster Kecamatan di Kabupaten Semarang berdasarkan Potensi Desa menggunakan Metode Ward dan Single Linkage. Jurnal Gaussian, 5(4), pp.801810.

Febrian, A.D.., 2012. Permainan Bergambar Sebagai Metode Penyuluhan untuk Meningkatkan Pengetahuan tentang Penyakit Demam Berdarah. Unnes Journal 
of Public Health, 1(1), pp.8-11.

Hakim, R.N., 2018. Pengaruh Jumlah Kasus HIV/AIDS dan Cakupan Rumah Sehat terhadap Jumlah Kasus Tuberkulosis di Provinsi Jawa Timur. Jurnal Biometrika dan Kependudukan, 7(2), pp.141-148.

Hartanti, W., Lubis, S.N. and Butar-Butar, H., 2013. Dampak Pertambahan Penduduk, Akses Pangan dan Usaha Pengentasan Kemiskinan terhadap Jumlah Penduduk Miskin di Sumatera Utara. Journal on Social Economic of Agriculture and Agribusiness, 2(5), pp.1-15.

Indonesian Government Regulation Number 16 of 2005 Concerning Pengembangan Sistem Penyediaan Air Minum.

Indonesian Ministry of Health Decree Number 1428/ MENKES/SK/XII/2006 Concerning Pedoman Penyelenggaraan Kesehatan Lingkungan Puskesmas.

Kuntoro, 2011. Metode Statistik. Revised ed. Surabaya: Pustaka Melati.

Mukti, S.T.M. and Wibowo, A., 2017. Pemetaan Wilayah Kesehatan Ibu dan Anak di Provinsi Jawa Timur Tahun 2014. Jurnal Ilmiah Kebidanan (Scientific
Journal of Midwifery), 3(1), pp.11-21.

Norihwadziyah, I.V. and Keman, S., 2013. Hubungan Kesehatan Rumah dengan Kejadian ISPA pada Anak Balita di Wilayah Kerja Puskesmas Baamang I Kecamatan Baamang Kabupaten Kotawaringin Timur. Jurnal Kesehatan Lingkungan, 7(1), pp.171-178.

Nuraini, I., 2017. Kualitas Pertumbuhan Ekonomi Daerah Kabupaten/Kota di Jawa Timur. In: Seminar Nasional \& Call for Paper, FEB Unikama 'Peningkatan Ketahanan Ekonomi Nasional dalam Rangka Menghadapi Persaingan Global' Malang. Malang.

Pratiwi, N., Santosa, D.B. and Ashar, K., 2018. Analisis Implementasi Pembangunan Berkelanjutan di Jawa Timur. Jurnal Ilmu Ekonomi dan Pembangunan (JIEP), 18(1), pp.1-13.

Ragil, D.W.L. and Dyah, Y.P.S., 2017. Hubungan antara Pengetahuan dan Kebiasaan Mencuci Tangan Pengasuh dengan Kejadian Diare pada Balita. Jurnal of Health Education, 2(1), pp.39-46. 